\title{
Unbroken Will to Live
}

\section{The Power of Spiritual Resistance in the Theresienstadt Ghetto}

\author{
AUTHOR: Tianna Voort \\ EDITED BY: Eli Feldman, Esti Azizi, and Marisa Coulton
}

Life in the Theresienstadt ghetto was distinct from the rest of the ghettos established in Nazioccupied Europe. The Nazis used Theresienstadt as a form of propaganda to masquerade their inhumane treatment of the Jews, calm the fears of the international community, and draw attention away from their creation of death camps throughout Eastern Europe. Famous Jews were sent to Theresienstadt from 1941-1944, which led to a disproportionate number of cultural elite in the ghetto. The Nazis' plan to use Theresienstadt as a model ghetto allowed for the development of a distinct and flourishing cultural life, which included music, opera, theatre, art exhibitions, poetry, lectures, and literature. Importantly, such prosperous cultural life became a form of spiritual resistance and, in turn, emerged as a crucial means of survival for the Jews in Theresienstadt.

The first step of the Nazis' plan to destroy the Jews of Europe was the implementation of restrictive laws designed to dehumanize and demoralize the prosperous Jewish community. The establishment of the ghettos was an important phase in the implementation of this plan, which systematically removed Jews from society. By centralizing the Jews in ghettos, the Nazis created a physical divide between the Jewish and nonJewish populations and, in turn, furthered their efforts to dehumanize the Jews.

While Jews in the Theresienstadt ghetto lacked the tools for armed combat, they relied on spiritual tools as a means of resistance. In 1968, historian and Holocaust survivor Meir "Mark" Dworzecki used the term Amidah to define a spiritual resistance that was non-violent in nature. Amidah is a Hebrew word that translates to 'stand.' The term Amidah encompasses all Jewish expressions of non-conformism, which were intended to oppose the Nazis' goal to dehumanize and deprive the Jews of their humanity. In the ghettos, the Jews' ability to resist German efforts of dehumanization demonstrated immense courage and heroism of the spirit. ${ }^{1}$ Jews in the ghetto did not passively accept their fates; instead, they lived their lives as human beings with hope for a better future, and showed the Nazis that they could not succeed in destroying their humanity or dignity. In the face of dire suffering, the creation of cultural activities represented an essential means of spiritual resistance against the Nazis' desire to destroy Jewish humanity. These activities shared two main goals: to elevate life under difficult circumstances, and to affirm the humanity of Jewish life.

In the Theresienstadt ghetto, the prisoners clung to cultural activities as a moral lifeline, but their 'intoxication' with cultural activities has generated considerable controversy among Holocaust survivors and historians. H.G. Adler, a noted scholar and Holocaust survivor, argues that the cultural developments in the ghetto were a way for Jews to distort and deny reality. Adler contends that this 'intoxication' was detrimental to prisoners' lives in the camp because the reliance on fantasy and illusion reflected a regression to a childlike state. ${ }^{2}$ However, the majority of survivors disagree with Adler's conclusion that the ability to psychologically remove oneself from the camp atmosphere was harmful. Theresienstadt survivor Gerty Spies, draws the antithetical conclusion that the primary purpose of these activities was to help the prisoners forget the reality of life for 
as long as possible. ${ }^{3}$ These short periods of psychological escape provided the prisoners with spiritual fortification that helped them persist through the difficulties of daily life in the camp. Jana Sedova, another Theresienstadt survivor, claims that the evening entertainment "gave dignity to the prisoners," and that "this spark gave light and warmth for several days." ${ }^{4}$ Historians Janet Blatter and Sybil Milton have demonstrated that the creation of art was a survival strategy that allowed for a temporary escape from reality. ${ }^{5}$ Furthermore, historian Miroslav Karney argues that art was 'the prisoners' weapon of defense against human decimation. It became the battlefield where the struggle to maintain the camp spirit was waged."6 For Holocaust survivor, Jacob Jacobsohn, the small pleasures of artistic creation were essential to counterbalancing the misery of the deportations in the camp. ${ }^{7}$

In 1780, Terezín was founded as a military compound in the Czech Republic. However, by the 1930s, the compound was a town in which 3,700 Czech civilians lived. ${ }^{8}$ In 1941, the Jewish community in Prague appealed to the German administration to establish a ghetto within the borders of the Protectorate, rather than send the Jews of Bohemia and Moravia to camps in the East. ${ }^{9}$ The town of Terezín was chosen by the Nazis as the location for this ghetto-camp, which was renamed Theresienstadt. ${ }^{10}$ The first transport of 342 young men from Prague arrived at the ghetto on November 24, 1941. While the deportees were promised comfortable billets, paid work, and permission to maintain correspondence with their families, this did not prove to be the case. The conditions of the camp were dismal, and the deportees were given no compensation for their work. ${ }^{11}$ Transportations to Theresienstadt of women, children, and the elderly began in early December, 1941. In January, 1942, deportations from Theresienstadt to the extermination camps in the East commenced. ${ }^{12}$ Consequently, Theresienstadt became a transit station for Jews being sent to death camps. These transports continued until October, 1944, and became one of the most constant features of life in the ghetto. ${ }^{13}$ It was under this constant threat of deportation that the Jews of the ghetto lived.

To give Theresienstadt the appearance of a self-governing community, the Nazis established the Council of Elders, managed by respected members of the Jewish community. The Council of Elders was headed by Jakub Edelstein, to whom the Nazis gave the title of 'Elder of the Jews'. Edelstein and his men were responsible for the daily activities in the camp such as construction of billets, work assignments, and food allotments. While this administration was given limited autonomy, it attempted to mitigate the distress of German directives on the Jews primarily by addressing prisoner concerns regarding hunger, sickness, and despair. ${ }^{14}$

Theresienstadt was designed as a ghetto to house Jews whose unexplained disappearance would be noticed by the international community. The purpose of congregating the cultural elite in one place was to present Theresienstadt as a "model ghetto" where Jews lived comfortably. The Nazis attempted to show the world that they were solving the "Jewish Question" in a humane fashion. These privileged populations included famous Czech artists, musicians, writers, and scholars, First World War heroes, and children or spouses in mixed marriages. ${ }^{15}$ After the Wannsee Conference in 1942, Prague's cultural elite were joined by those from Germany, Austria, and the Netherlands. ${ }^{16}$ Theresienstadt thus became a centre for the 'leading' continental Jewry. ${ }^{17}$ The growth in the number of cultural elite in the ghetto led to the development of a vibrant cultural life. ${ }^{18}$

When the camp was initially established, all cultural activities were banned by the Nazis. However, there is evidence that clandestine cultural activities began almost immediately in Theresienstadt. A party was organized by the first two transports (A-K 1 and A-K 2) within the first month of the ghetto's establishment. Among the workers, there were musicians, actors, and poets, and, as a result, there was little difficulty organizing 
entertainment. The group created an orchestra with a recorder, a harmonica, an accordion, and a wash bin for a drum. ${ }^{19}$ At first, there was no formal organization to the cultural activities, which were carried out without the knowledge of the Nazis. Nevertheless, these improvised activities effectively built resistance, affirmed life, and helped overcome the hardships of life in the camp.

To advance the idea of the ghetto as a Jewish settlement, the Schutzstaffel ("S.S."), Hitler's major parliamentary organization, began to allow the proliferation of cultural activities. Eventually, the S.S. even actively encouraged the development of artistic endeavors in the ghetto. ${ }^{20}$ The lift of the official ban on culture led to a deluge of activities. ${ }^{21}$ In 1942, with the permission of the S.S., the Council of Elders established the Freizeitgestaltung (Administration of Leisure Activities) which permitted prisoners to create cultural programs in their 'free time'. Performances were held for other inmates as well as for Nazi officers. ${ }^{22}$ The establishment of the Freizeitgestaltung was significant for the development of cultural life in Theresienstadt. It meant that all future cultural activities were implemented with German approval, even if they were sometimes subjected to Nazi censorship. In addition, the employees of the Freizeitgestaltung were pardoned from manual work to focus on their artistic developments, and the Council modestly compensated the performers with extra food rations. ${ }^{23}$ Artists, composers, and writers were given allotted time to create new works. At a time when all Jewish expression in Nazi occupied Europe was being silenced, the development of new Jewish cultural material in Theresienstadt sanctioned by the Nazis was extremely significant. ${ }^{24}$

The Freizeitgestaltung supervised poetry readings, operas, plays, music recitals, lectures, and other artistic activities. While attendance at these performances was voluntary, the turnout was always high, and prisoners were often forced to stand to accommodate the large audiences. ${ }^{25}$ The Freizeitgestaltung also attempted to make musical instruments available to musicians.
These instruments were obtained from the property of disbanded Jewish communities. ${ }^{26}$ The administration even convinced the S.S. to bring several pianos into the ghetto that had been confiscated from Jewish homes. ${ }^{27}$ These instruments made concerts in the ghetto possible. While the Nazis encouraged the creation of the Freizeitgestaltung, they did not anticipate the extent to which cultural activities would develop in the ghetto. What began as a Nazi propaganda tool became a weapon of intellectual and spiritual resistance for the Jews of Theresienstadt. ${ }^{28}$

Music flourished in Theresienstadt and played an important role in prisoners' lives. ${ }^{29}$ Many classical musical works such as The Bartered Bride, The Marriage of Figaro, The Magic Flute, and Verdi's Requiem were performed in Theresienstadt. Many talented musicians and composers were deported to Theresienstadt, including the former conductor of the Royal Danish Symphony, the former concertmaster of Holland's Concertgebouw Orchestra, and the former Deputy Concertmaster of the Czechoslovakian National Symphony. ${ }^{30}$

One of these talented conductors was Rafael Schachter, who established a choral group in Theresienstadt that comprised some of the best vocalists in Europe. The group originally sang informal arrangements of folk songs. However, with the arrival of world-famous composer Gideon Klein, the group expanded their repertoire to include Klein's arrangements of Czech, Slovak, Hebrew, and even Russian folk songs. ${ }^{31}$ Klein also created original compositions for the choral group. ${ }^{32}$ In her memoir, Theresienstadt survivor Gerty Spies described the profound impact of her first experience listening to Schachter's choral group:

Some women sang with beautiful trained voices and carried us off for an hour into the world of oblivion. I can't remember their names, yet I am grateful to them still today. How richly rewarded one left such performances is difficult to describe. Even more 
exalting than our artistic pleasure, often diminished by the circumstances, was the effect of the triumph on our spirits... Stephan Zweig's immortal words: "You can conquer a people, but not its spirit!" became more vivid for me than ever before. ${ }^{33}$

For Spies, the choral performance was a moment of spiritual liberation, which lifted her spirits, and this, to her, was a form of resistance.

Alice Herz-Sommer was also a musician interred in Theresienstadt. She was a classically trained pianist from Prague. During her time in Theresienstadt, she played over a hundred concerts, often playing all of Chopin's Études from memory. Herz-Sommer credits her survival in Theresienstadt to her ability to continue to play music. She said that the music gave her hope, and knew that if she could play music, life could not be terrible. In the documentary, The Lady in Number 6: Music Saved My Life, Zdenka Fantlova, another survivor of Theresienstadt, discussed the effect that Alice's music had on her life in the ghetto. She said that "it was magic to hear this music in that kind of surrounding, which you don't realize until it's over. So, you come sort of back to earth and see where you are and how much it was a moral support, it was not entertainment as most people thought... It had a much bigger value." ${ }^{34}$ The spiritual resistance of Alice's music allowed her to hold onto her humanity and joy, and transported her audiences to a better mental place in which they were not hungry, sick, or tired. It was a place where they were free. ${ }^{35}$

Many classical operas were performed in Theresienstadt including Tosca, Aida, Carmen, Die Fledermaus, and La Boehme. ${ }^{36}$ The most famous Theresienstadt opera was Brundibár. The children's' opera, Brundibár, was the most performed and most highly attended concert in Theresienstadt. Brundibár was not written in the camp, but was written by a Jewish composer, Hans Krása, in 1938 during the ban on Jewish cultural creations. Brundibár was firmly rooted in
Jewish clandestine musical activity. ${ }^{37}$ The opera was popular because of its thinly veiled political message about the ability of the Jewish community to overcome adversity. The antagonist, Brundibár, became an allegory for Hitler. The triumph of the children, who came to represent the prisoners, appealed to the audience. ${ }^{38}$ The themes of uniting against evil, overcoming adversity, and the triumph of the underdog provided hope to the Jews of Theresienstadt. ${ }^{39}$ Brundibár used music to defy the Nazi system and functioned as a form of spiritual resistance. ${ }^{40}$

Brundibár also functioned as a method of resistance for the child performers. The children in Theresienstadt were not able to experience a normal childhood and, as a result, the cultural elements of the camp served as a reminder of childhood before their incarceration. It was a way in which they could experience their childhood anew. The children related to the story of Brundibár, and cheered loudly when the villain was defeated. ${ }^{41}$ One of the survivors of the cast, Ella Weissberger, said that the "show meant more to its young performers than food, for it helped them overcome feelings of helplessness while giving themselves a sense of membership in the human race." 42 The ability to maintain a feeling of humanity and the preservation of hope were both important ways in which the performance of Brundibár functioned as spiritual resistance for the children in Theresienstadt.

Brundibár was first performed in Theresienstadt in September, 1943, and was performed another 55 times. ${ }^{43}$ The Nazis also included scenes from Brundibár in the propaganda film they made about the Theresienstadt ghetto. ${ }^{44}$ Despite its obvious political message, the Nazis used Brundibár as a piece of propaganda to illustrate the humane treatment of the prisoners. ${ }^{45}$ The Nazis underestimated Brundibár's powerful political statement and, thus, did not recognize the role it served as a tool of resistance within the camp. ${ }^{46}$ 
While concerts and operas were a communal form of spiritual resistance, there were also artistic endeavors in Theresienstadt that reflected personal forms of resistance. Poetry was one of the most common forms of cultural creation in the ghetto. Poetry became a creative way of documenting and processing the horror of life in the ghetto. ${ }^{47}$ Poems written in Theresienstadt documented individual experiences of the Holocaust. Writers in Theresienstadt were able to preserve their identities in an environment in which the Nazis attempted to dehumanize them. The creation of poetry was situated within the Jewish tradition of the Torah and Talmud, both of which teach that evil that has been witnessed must be reported so that it will never be forgotten. ${ }^{48}$ In this way, the writing of poetry not only facilitated the remembrance of the Holocaust, it also continued Jewish traditions.

Gerty Spies further discussed the way poetry in the camp functioned as a form of spiritual resistance. The horror of the camp was overwhelming, and Spies found herself falling into profound depression. It was at that point when she decided to start writing poetry. Spies thought to herself that if she began writing, "Your thoughts will not again and again grope along this tortuous path of suffering, this homesickness. They will have to concentrate - each minute, each second - so that perhaps you can bend your pain into an expression of your imagination...only your body will still be here." 49 For Spies, writing poetry was a way of escaping the ghetto and transporting her mind to a better place. Spies claims that it was poetry that spiritually armed her to be able to survive a severe case of pneumonia in the spring of 1943. The moments that Spies spent writing poetry were moments of jubilation, joy, and astonishment, and served as an escape from hunger, weakness, cold, and homesickness. ${ }^{50}$ Writing poetry was more than a creative outlet - it was a survival strategy. ${ }^{51}$

While poetry was mostly a private affair, world-renowned poet, Philipp Manes, organized secret poetry competitions for the prisoners. These competitions received over 200 entries. The best poems were selected by a panel of judges, and the winners were given the opportunity to recite their compositions in front of an audience. ${ }^{52}$ Gerty Spies describes these poetry recitals as "a referendum as to whose voice could warm the listeners' hearts best." 53 These performances not only validated the creative work of the writers, but also created a place in which communal experiences were validated. The poems created a sense of solidarity through shared experiences and feelings.

Artists in Theresienstadt performed a personal and private form of spiritual resistance through their drawings. Artists in the ghetto worked in a studio above the library where they produced artwork according to Nazi orders. While artists such as Otto Unger, Frita "Fritz" Taussig, Peter Kien, and Leo Haas officially worked on technical designs for construction in the ghetto, they also clandestinely drew ghetto life and figures, which depicted the horrors of daily realities. Drawings included "pictorial testimonial of the hangings, of old people scrounging in the garbage, convoys leaving for unknown destinations, sick rooms, living quarters with no space to breathe." 54 These drawings were hidden in ghetto walls, buried in tin boxes, and sometimes hidden in the library along with other documents in the hopes they would be found after the War. According to artist Leo Haas, "we hid four hundred of my works and some of Fritta's in the barrack wall."55 The artists in Theresienstadt recorded the reality of life in the ghetto, which was far different from the way it was portrayed by the Nazis. Some of the drawings were even smuggled out of the ghetto through the Czech underground movement. ${ }^{56}$ Unfortunately, some of these drawings fell into Nazi hands in 1944, leading five artists to be convicted of "propaganda hostile to the Reich". The result was that these artists, along with their families, were tortured and executed. ${ }^{57}$ Nevertheless, by documenting and preserving images of the dismal life in the ghettos, the artists participated in concrete resistance against the Nazi administration. 
The Jews of the Theresienstadt ghetto were desperate for any form of escape from everyday life. ${ }^{58}$ Unlike other ghettos and camps, the Nazis condoned and encouraged the Jews to participate in cultural activities. However, the Nazis did not anticipate that this decision would foster the development of a deep spiritual resistance within the camp. While the prisoners may have been too weak to physically resist, the power gained through cultural activities gave many people the will and desire to survive. George Berkley claims that without the cultural endeavors in Theresienstadt, there would have been higher rates of despair and depression, which would have resulted in greater occurrences of illness and death. Therefore, the cultural activities of the ghetto became a legitimate means of survival. ${ }^{59}$

The Nazis attempted to destroy the humanity of the prisoners. However, cultural productions in Theresienstadt allowed Jews to preserve their humanity, express their identity, and maintain a cultural cohesion. ${ }^{60}$ The plays, poetry readings, operas, and musical concerts created a spiritual bond between the inmates. ${ }^{61}$ Through the active cultivation of cultural institutions, Jews made a powerful statement about their will and ability to survive. Jews in the Theresienstadt ghetto lived under the constant fear of death. For Theresienstadt survivor Norbert Frýd, the prisoners' involvement in cultural activities illustrated their "unbroken will to live." 62 While they lacked the tools and the strength for physical resistance, prisoners at Theresienstadt participated in spiritual resistance through their involvement in cultural endeavors. Art and culture allowed prisoners to temporarily escape from the dismal life in the ghetto, and helped prisoners affirm their humanity and their undying will to live.

\section{ENDNOTES:}

1. Joseph Rudavsky, To Live with Hope, To Die With Dignity: Spiritual Resistance in the Ghettos and Camps (Northvale, NJ: University Press of America, 1997), 29-30.

2. H. G Adler, Belinda Cooper, and Amy Loewenhaar-Blauweiss, Theresienstadt, 1941-
1945: The Face of a Coerced Community (New York NY: Cambridge University Press, 2017), 518. 3. Gerty Spies, My Years in Theresienstadt: How One Woman Survived the Holocaust (Amherst: Prometheus Books, 1997), 16.

4. Terezin (Prague: Council of Jewish

Communities in the Czech Lands, 1965), 224.

5. Janet Blatter and Sybil Milton, Art of the Holocaust (New York: Rutledge Press, 1981).

6. George E. Berkley, Hitler's Gift: The Story of Theresienstadt (Boston: Braden Books, 1993), 142.

7. Jacob Jacobsohn, "The Daily Life, 1943-1945," (London, 1946: Yad Vashem Archives), 12.

8. Zdenek Lederer, Ghetto Theresienstadt

(London: Howard Fertig Inc, 1983), 2.

9. Ibid., 13.

10. David Pariser, "A Woman of Valor: Freidl Dicker-Brandeis, Art Teacher in Theresienstadt Concentration Camp," Art Education 61, no. 4 (2008): 8. Theresienstadt is considered a ghettocamp because of its dual function as a ghettolabor camp for incarcerated Jews, as well as a transit camp for transports to death camps in the East.

11. Lederer, Ghetto Theresienstadt, 14.

12. Ibid., 15.

13. Ibid, 22.

14. Miriam Intrator, "'People Were Literally Starving for Any Kind of Reading': The Theresienstadt Ghetto Central Library, 19421945," Library Trends 55 (Winter, 2007): 514. 15. Jennifer Blackwell, "Brundibar in Terezin: Music as Spiritual Resistance During the Holocaust," Nota Bene: Canadian Undergraduate Journal of Musicology 4 (2010), 20-21, 514.

16. Ruth Frenk, "Freizeitgestaltung--vocal music in Theresienstadt, 1942-1944," Journal of Singing 70, no. 2 (2013): 147.

17. Berkley, Hitler's Gift, 11.

18. Blackwell, "Brundibar in Terezin," 20-21.

19. Ruth Bondy, "Elder of the Jews": Jakob Edelstein of Theresienstadt (New York: Grove Press, 1989), 291. These instruments were smuggled into the ghetto in defiance of the general ban on instruments. 
20. Berkley, Hitler's Gift, 126.

21. Ruth Schwertfeger, Women of Theresienstadt: Voices From a Concentration Camp (New York:

Berg Publishers Limited, 1989), 72.

22. Frenk, "Freizeitgestaltung," 147.

23. Berkley, Hitler's Gift, 127.

24. Joža Karas, Music in Terezín 1941-1945

(Hillsdale: Pendragon Press, 2008), 14.

25. Spies, My Years in Theresienstadt, 14.

26. Lederer, Ghetto Theresienstadt, 125.

27. Berkley, Hitler's Gift, 129.

28. Lederer, Ghetto Theresienstadt, 125.

29. Blackwell, "Brundibar in Terezin," 17.

30. Berkley, Hitler's Gift, 10.

31. Karas, Music in Terezín, 19.

32. Frenk, "Freizeitgestaltung," 149.

33. Spies, My Years in Theresienstadt, 78.

34. The Lady in Number 6: Music Saved My Life, directed by Malcolm Clarke (San Francisco: Reed Entertainment, 2013).

35. Ibid.

36. Blackwell, "Brundibar in Terezin," 21.

37. Ibid., 18.

38. Ibid., 23.

39. Ibid., 19.

40. Ibid., 17-18, 25.

41. Thelma Gruenbaum, Nešarim: Child Survivors of Terezín (Portland: Vallentine Mitchell, 2004), 48.

42. Berkley, Hitler's Gift, 142.

43. Blackwell, "Brundibar in Terezin," 19.

44. Gruenbaum, Nešarim, 49.

45. Blackwell, "Brundibar in Terezin," 21.

46. Ibid., 25.

47. Sandra Alfers, "Poetry from the Theresienstadt

Transit Camp, 1941-1945," Rocky Mountain

Review 64, no. 1 (2010): 51.

48. Ibid.

49. Spies, My Years in Theresienstadt, 64.

50. Ibid., 70-71.

51. Schwertfeger, Women of Theresienstadt, 73.

52. Philipp Manes, As If It Were Life: A WWII

Diary From the Theresienstadt Ghetto, (New York:

Pargrave MacMillan, 2005), 59.

53. Spies, My Years in Theresienstadt, 105.

54. Bondy, Elder of the Jews, 348.

55. Mary S. Costanza, The Living Witness: Art in the Concentration Camps and Ghettos, (New York: London Free Press, 1982), 111. Excerpt from conversation with Leo Haas, June, 1979, in Berlin.

56. Norbert Troller, Theresienstadt: Hitler's Gift to the Jews, (Chapel Hill: The University of North Carolina Press, 1991), 135.

57. Lederer, Ghetto Theresienstadt, 120.

58. Intrator, "People Were Literally Starving," 513.

59. Berkley, Hitler's Gift, 142.

60. Blackwell, "Brundibar in Terezin," 25.

61. Spies, My Years in Theresienstadt, 16.

62. Berkley, Hitler's Gift, 142.

\section{BIBLIOGRAPHY:}

Adler, H. G., Belinda Cooper, and Amy LoewenhaarBlauweiss. Theresienstadt, 1941-1945: The Face of a Coerced Community. New York: Cambridge University Press, 2017.

Alfers, Sandra. "Poetry from the Theresienstadt Transit Camp, 1941-1945." Rocky Mountain Review 64, no. 1 (2010): 4770.

Berkley, George E., Hitler's Gift: The Story of Theresienstadt. Boston: Braden Books, 1993.

Blackwell, Jennifer (2011) "Brundibar in Terezin: Music as Spiritual Resistance During the Holocaust," Nota Bene: Canadian Undergraduate Journal of Musicology:Vol. 4: Iss. 1, Article 3. https:// ir.lib.uwo.ca/notabene/vol4/iss1/3.

Blatter, Janet and Sybil Milton. Art of the Holocaust. New York: Rutledge Press, 1981.

Bondy, Ruth. "Elder of the Jews": Jakob Edelstein of Theresienstadt. 1st ed. New York: Grove Press, 1989.

Costanza, Mary S. The Living Witness: Art in the Concentration Camps and Ghettos. 
New York: London Free Press, 1982.

Frenk, Ruth. "Freizeitgestaltung--vocal music in Theresienstadt, 1942-1944." Journal of Singing 70, no. 2 (2013): 147+. Academic OneFile (accessed January 20, 2018). http://link.galegroup.com.proxy1.lib.uwo. ca/apps/doc/A352753353 AONE?u=lo nd95336\&sid=AONE\&xid=42563327.

Gruenbaum, Thelma. Nešarim: Child Survivors of Terezín. Portland: Vallentine Mitchell, 2004.

Hutcheon, Linda and Michael Hutcheon. 2000.

"“Death, Where is Thy Sting?" the Emperor of Atlantis." The Opera Quarterly 16 (2): 224-239.

doi:10.1093/oq/16.2.224.

http://resolver.scholarsportal.info/ resolve/07360053/v16i0002/224_witsteoa.

Intrator, Miriam, "'People Were Literally Starving for Any Kind of Reading': The Theresienstadt Ghetto Central Library, 1942-1945." Library Trends 55 (Winter, 2007): 513-522.

Jacobsohn, Jacob. The Daily Life, 1943-1945. London, 1946: Yad Vashem Archives.

Karas, Joža. Music in Terezín 1941-1945. 2nd ed. Hillsdale: Pendragon Press, 2008. Lederer, Zdenek. Ghetto Theresienstadt. London: Howard Fertig Inc, 1983.

Manes, Philipp. As If It Were Life: A WWII Diary From the Theresienstadt Ghetto. New York: Pargrave MacMillan, 2005.

Pariser, David. "A Woman of Valor: Freidl Dicker-Brandeis, Art Teacher in Theresienstadt Concentration Camp." Art Education 61, no. 4 (2008): 6-12. http://www.jstor.org.proxy1.lib.uwo.ca/ stable/20694738.
Rudavsky, Joseph. To Live with Hope, To Die With Dignity: Spiritual Resistance in the Ghettos and Camps. Northvale: University Press of America, 1997.

Schwertfeger, Ruth. Women of Theresienstadt: Voices From a Concentration Camp. New York: Berg Publishers Limited, 1989.

Spies, Gerty. My Years in Theresienstadt: How One Woman Survived the Holocaust. Amherst: Prometheus Books, 1997.

Terezin. Prague: Council of Jewish Communities in the Czech Lands, 1965.

The Lady in Number 6: Music Saved My Life. Directed by Malcolm Clarke. San Francisco: Reed Entertainment, 2013.

Troller, Norbert. Theresienstadt: Hitler's Gift to the Jews. Chapel Hill: The University of North Carolina Press, 1991. 